\title{
Hormonal regulation of aquaporin 3: opposing actions of prolactin and cortisol in tilapia gill
}

\author{
Jason P Breves', Mayu Inokuchi'2,3, Yoko Yamaguchi'2, Andre P Seale², \\ Bethany L Hunt', Soichi Watanabe ${ }^{3}$, Darren T Lerner ${ }^{2,4}$, Toyoji Kaneko ${ }^{3}$ \\ and E Gordon Grau² \\ 'Department of Biology, Skidmore College, Saratoga Springs, New York, USA \\ 2Hawai'i Institute of Marine Biology, University of Hawai'i at Mānoa, Kāne'ohe, Hawai'i, USA \\ 3Department of Aquatic Bioscience, Graduate School of Agricultural and Life Sciences, \\ University of Tokyo, Bunkyo, Tokyo, Japan \\ 4University of Hawai'i Sea Grant College Program, University of Hawai'i at Mānoa, Honolulu, Hawai'i, USA
}

Correspondence should be addressed to J P Breves Email jbreves@skidmore.edu

\begin{abstract}
Aquaporins (Aqps) are expressed within key osmoregulatory tissues where they mediate the movement of water and selected solutes across cell membranes. We leveraged the functional plasticity of Mozambique tilapia (Oreochromis mossambicus) gill epithelium to examine how Aqp3, an aquaglyceroporin, is regulated in response to osmoregulatory demands. Particular attention was paid to the actions of critical osmoregulatory hormones, namely, prolactin (Prl), growth hormone and cortisol. Branchial aqp3 mRNA levels were modulated following changes in environmental salinity, with enhanced aqp3 mRNA expression upon transfer from seawater to freshwater (FW). Accordingly, extensive Aqp3 immunoreactivity was localized to cell membranes of branchial epithelium in FW-acclimated animals. Upon transferring hypophysectomized tilapia to FW, we identified that a pituitary factor(s) is required for Aqp3 expression in FW. Replacement with ovine Prl (oPrl) was sufficient to stimulate Aqp3 expression in hypophysectomized animals held in FW, an effect blocked by coinjection with cortisol. Both oPrl and native tilapia Prls ( $\operatorname{tPrl}_{177}$ and $\mathrm{tPrl}_{188}$ ) stimulated aqp3 in incubated gill filaments in a concentration-related manner. Consistent with in vivo responses, coincubation with cortisol blocked oPrl-stimulated aqp3 expression in vitro. Our data indicate that Prl and cortisol act directly upon branchial epithelium to regulate Aqp3 in tilapia. Thus, within the context of the diverse actions of Prl on hydromineral balance in vertebrates, we define a new role for Prl as a regulator of Aqp expression.
\end{abstract}

\author{
Key Words \\ - aquaporin \\ - prolactin \\ - cortisol \\ - gill \\ - osmoregulation
}

Journal of Endocrinology (2016) 230, 325-337

\section{Introduction}

Aquaporin (Aqp) proteins are important mediators of transepithelial fluid transport and cell volume regulation in vertebrate tissues (Boury-Jamot et al. 2006, Verkman 2012). Spanning the plasma membrane, Aqps facilitate passive movements of water and, in some cases, small nonionic compounds. Diverse activities, such as cell migration, neural signaling, fat metabolism and osmotic balance, rely upon the regulated movement of water and solutes via Aqps. Accordingly, misregulated or genetic interruption of Aqp function underlies a host of

Published by Bioscientifica Ltd 
disease states such as polyuria, edema, cataracts, diabetes insipidus, and obesity (Verkman 2012, Papadopoulus \& Verkman 2013). A nuanced understanding of how Aqps underlie both physiological and disease states requires varied experimental approaches and model systems that reflect the diverse roles of Aqps in vertebrate systems.

Owing to the osmoregulatory demands associated with living in aqueous environments, teleost fishes are intensely studied to build the mechanistic models of how vertebrate ion-transporting epithelia are regulated. A limited subset $(<10 \%)$ of teleosts (Schultz \& McCormick 2013) has evolved the capacity to thrive in environments ranging from freshwater (FW) to seawater (SW) by efficiently modulating effectors of ion and water transport in the gill, kidney, gut, and urinary bladder (Marshall \& Grossell 2006). The evolved capacities of these 'euryhaline' fishes to tolerate disparate salinities necessitate that epithelial surfaces in direct contact with external conditions possess sensory systems that detect changes in ambient osmolality (Fiol \& Kültz 2007). These osmosensory systems couple with regulatory systems that both protect cellular homeostasis and modulate the expression of ion transport effectors responsible for maintaining homeostasis of the organism (Fiol \& Kültz 2007, Tse et al. 2007).

The vertebrate Aqp superfamily consists of 17 classes of Aqps. Teleosts (e.g., Atlantic salmon (Salmo salar)) may express up to 42 paralogs (Finn et al. 2014). Multiple teleost Aqps are expressed in osmoregulatory epithelia; for example, Aqp3, an aquaglyceroporin, which transports water, glycerol, and urea, has been studied in a suite of euryhaline teleosts with particular attention to its expression following changes in salinity. In surveyed species, branchial aqp3 gene expression is markedly elevated in FW- versus SW-acclimated animals (Cutler \& Cramb 2002, Lignot et al. 2002, Tse et al. 2006, Tipsmark et al. 2010, Whitehead et al. 2010, Jung et al. 2012, Madsen et al. 2014, Moorman et al. 2015). Although the functional significance of plastic aqp3 expression in the gill stands unresolved, regulated transepithelial water movement, via Aqp3, appears unlikely on the basis that branchial water exchange is disadvantageous for fish in both FW and SW environments (Cerdà \& Finn 2010). Alternatively, the roles for Aqp3 in mediating regulatory cell volume and/or autonomous osmosensing capacities of the gill have been proposed (Watanabe et al. 2005, Cutler et al. 2007, Madsen etal. 2015). With salinity-dependent patterns of aqp3 expression clearly evident from studying fishes in a comparative fashion, there remains little knowledge of how Aqp3 is actually regulated. In mammalian epidermis,
Aqp3 is expressed extensively in the plasma membrane of keratinocytes where it mediates water and glycerol transport supporting skin hydration/elasticity (BouryJamot et al. 2006). Although the extent of hormonal control of Aqp3 in mammalian epidermis is similarly unresolved, it is noteworthy that both tissues operate as barriers between the organism and the environment.

The endocrine system coordinates the processes supporting hydromineral balance by orchestrating the expression, localization, and activities of subcellular effectors of solute and water transport. These effectors include ion channels, cotransporters, exchangers, $\mathrm{Na}^{+} /$ $\mathrm{K}^{+}$-ATPases, and Aqps (Kaneko et al. 2008, Konno et al. 2010). Decades of comparative study have revealed that a conserved function for prolactin ( $\mathrm{Prl}$ ) across vertebrates is the regulation of ion and water transport (Bole-Feysot et al. 1998). In teleosts, Prl promotes phenotypes associated with FW acclimation, whereas growth hormone (Gh) supports phenotypes associated with SW acclimation (Hirano 1986, McCormick 2001). Cortisol, under the control of adrenocorticotropic hormone, can seemingly support both FW and SW acclimation (McCormick 2001). The dynamics of plasma Prl, Gh, and cortisol in response to changes in salinity are in strong agreement with their specific actions in coordinating physiological responses to FW and/or SW (Yada et al. 1994, Seale et al. 2002, Kajimura et al. 2004). In light of the scant knowledge of how Aqp3 is regulated by endocrines, $\mathrm{Prl}, \mathrm{Gh}$, and cortisol represent plausible regulators of branchial Aqp3 in fishes.

Here, we employed hypophysectomy (Hx), and subsequent hormone replacement, to identify whether systemic hormones underlie the contrasting aqp3 gene and Aqp3 protein expression patterns observed between SW- and FW-acclimated Mozambique tilapia, Oreochromis mossambicus (Peters 1852). Upon finding the opposing effects of Prl and cortisol on Aqp3 in vivo, we incubated gill filaments to test whether Prl and cortisol have the capacity to regulate aqp3 in a gill-autonomous fashion. Our collective findings provide the first evidence that Prl directs the expression of an Aqp in a vertebrate, and moreover, that cortisol has the capacity to block this action.

\section{Materials and methods}

\section{Experimental animals}

Male tilapia (O. mossambicus; 50-125g) were selected from stocks maintained at the Hawai'i Institute of Marine Biology. Fish were maintained outdoors with a continuous

Published by Bioscientifica Ltd. 
flow of FW (municipal water; $1.05 \mathrm{mM} \mathrm{Na}^{+}, 0.55 \mathrm{mM} \mathrm{Ca}^{2+}$,

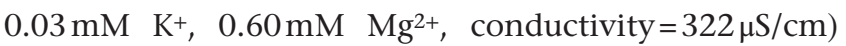
under natural photoperiod and fed a commercial diet (Classic Trout, Skretting, Tooele, UT, USA; 40\% crude protein, $12 \%$ crude fat, $3 \%$ crude finer, $\leq 12 \%$ ash, $\leq 2 \%$ sodium) twice a day. Water temperatures were maintained between 24 and $26^{\circ} \mathrm{C}$. The Institutional Animal Care and Use Committee of the University of Hawai'i approved all housing, surgical, and experimental protocols.

\section{Experiment 1: effect of salinity on aqp3 gene expression and immunoreactivity}

To assess the expression of aqp3 mRNA in FW- vs SW-acclimated animals, we sampled gill filaments from animals acclimated to either FW or SW $(34 \% 0,482 \mathrm{mM}$ $\mathrm{Na}^{+}, 545 \mathrm{mM} \mathrm{Cl}^{-}, 10.7 \mathrm{mM} \mathrm{Ca}^{2+}, 7.46 \mathrm{mM} \mathrm{K}^{+}, 52.6 \mathrm{mM}$ $\mathrm{Mg}^{2+}$, conductivity $=51 \mathrm{mS} / \mathrm{cm}$, Kāne'ohe Bay, Hawai'i, USA) for over 6 months. At sampling, all fish were lethally anesthetized in 2-phenoxyethanol (2-PE; $0.3 \mathrm{~mL} / \mathrm{L}$, Sigma), and 15-20 filaments were excised from the first gill arch, frozen in liquid nitrogen, and stored at $-80^{\circ} \mathrm{C}$ until RNA isolation. For whole-mount immunohistochemistry (IHC), the second gill arch was fixed for $24 \mathrm{~h}$ in $4 \%$ paraformaldehyde (PFA) in $0.1 \mathrm{M}$ phosphate buffer (PB; $\mathrm{pH} 7.4$ ) at $4^{\circ} \mathrm{C}$ and subsequently stored in $70 \% \mathrm{EtOH}$. Four tanks (500 L; two SW and two FW) were employed for a pair of salinity transfer experiments. One SW tank was transitioned to FW by opening a FW valve and closing the SW valve; one FW tank was transitioned to SW by opening a SW valve and closing the FW valve. Transitions between salinities were completed within $1 \mathrm{~h}$. At 6 and $24 \mathrm{~h}$ after the initial valve switching, fish $(n=6-10)$ were netted, lethally anesthetized, and sampled for gill filaments. Nontransferred controls were also sampled from the other two tanks at 6 and $24 \mathrm{~h}$.

\section{Experiment 2: effect of $\mathrm{Hx}$ on Aqp3 expression}

Hx was performed by the transorbital technique developed by Nishioka (1994). First, tilapia were anesthetized by immersion in 2-PE $(0.3 \mathrm{~mL} / \mathrm{L})$ in $\mathrm{FW}$. Following removal of the right eye and underlying tissue, a hole was drilled through the neurocranium, and the pituitary was aspirated with a modified Pasteur pipette. The orbit was then packed with a microfibrillar collagen hemostat (Ethicon, Somerville, NJ, USA), and fish were allowed to recover in brackish water (BW; $12 \%$ ). During the recovery period, the aspirated tissue was inspected under a stereo microscope. Hypophysectomized animals were not included in the experiment if a fully intact pituitary was not overtly evident. The success rate for these surgeries (removal of fully intact pituitaries) was $>95 \%$. Following recovery, fish were transferred to recirculating experimental aquaria containing aerated BW and treated with kanamycin sulfate (National Fish Pharmaceuticals, Tucson, AZ, USA). Sham operations were carried out in the same manner, but without aspiration of the pituitary.

In a pair of experiments, intact, sham-operated, and Hx tilapia $(n=5-11)$ were acclimated to SW or FW for 3 days. Following a 5-7-day postoperative period in BW $(12 \%)$, salinity transfers were conducted by adding SW or FW directly to recirculating aquaria. In the first group, SW was gradually added to the aquaria to raise the salinity to $23 \%$ after $90 \mathrm{~min}$. After $24 \mathrm{~h}$, SW was added again to raise the salinity to full-strength SW (34\%o) for the remainder of the experiment. In the second group, FW conditions were reached after $90 \mathrm{~min}$ and maintained for the duration of the experiment. Fish were not fed for the duration of the recovery and transfer periods. At sampling, all fish were lethally anesthetized, rapidly decapitated, and checked for completeness of $\mathrm{Hx}$ by postmortem inspection of the hypothalamic region under a stereo microscope. Gill filaments were collected as described previously for gene expression analyses and whole-mount IHC.

\section{Experiment 3: effect of hormones on Aqp3 expression in hypophysectomized tilapia}

In the next set of experiments, we investigated the effects of Prl, Gh, and cortisol on Aqp3 in Hx animals in FW and SW. Following a 3-day postoperative period in BW $(12 \%)$, fish $(n=5-11)$ were administered ovine Prl (oPrl; $5 \mu \mathrm{g} / \mathrm{g}$ body weight), ovine Gh (oGh; $5 \mu \mathrm{g} / \mathrm{g})$ or cortisol $(1 \mu \mathrm{g} / \mathrm{g})$, alone or in combination, by intraperitoneal injection concurrently with FW or SW acclimation. Hormone doses were selected based on previous experiments employing intraperitoneal injection in teleosts (Herndon et al. 1991, Eckert et al. 2001, Jackson et al. 2005, Breves et al. 2010c, 2014b). oPrl and cortisol (hydrocortisone) were purchased from Sigma; oGh was obtained from the National Hormone and Peptide Program (NIDDK-oGh-15, Torrance, CA, USA). The salinity transfers (FW and SW acclimation) were conducted in the same manner as in the preceding $\mathrm{Hx}$ experiment. Hormones were delivered in saline vehicle $(0.9 \% \mathrm{NaCl} ; 1.0 \mu \mathrm{L} / \mathrm{g}$ body weight). Cortisol was initially dissolved in ethanol and then added to

Published by Bioscientifica Ltd 
appropriate injection mixtures to achieve the desired concentrations. Ethanol (without cortisol) was added to all other injection mixtures at an equal dilution. The first injection occurred immediately before transfer to either FW or BW. Twenty-four hours later, fish were netted and given a second injection. Fish were then returned to aquaria and left undisturbed for $48 \mathrm{~h}$, after which time they were sampled as described previously. Sham-operated fish were injected with saline vehicle only. Intact fish were not included in the hormone replacement experiments because there were no significant differences between intact and shamoperated fish in the preceding experiment.

\section{Experiment 4: effects of oPrl, $\mathrm{tPrl}_{177}, \mathrm{tPrl}_{188}$ and cortisol on aqp3 expression in incubated gill filaments}

To identify the direct effects of Prl and cortisol on branchial aqp3 levels, we incubated filaments from the second and third gill arches following Watanabe and coworkers (2016). Filaments were collected from FW-acclimated tilapia. Briefly, individual filaments were cut from branchial arches, cut sagittally under a dissecting microscope, and then placed in 24-well plates (Becton Dickinson, Franklin Lake, NJ, USA) containing Leibovitz's L-15 medium (Life Technologies) supplemented with $5.99 \mathrm{mg} / \mathrm{L}$ penicillin and $100 \mathrm{mg} / \mathrm{L}$ streptomycin (Sigma). The medium was adjusted to $330 \mathrm{mOsm} / \mathrm{kg}$ by adding $5 \mathrm{~mol} / \mathrm{L} \mathrm{NaCl}$ solution. Two filaments were placed in each well, which contained $500 \mu \mathrm{L}$ incubation medium supplemented with 0 , $0.1,1,5$, and $10 \mu \mathrm{g} / \mathrm{mL}$ oPrl or $0,0.01,0.1,1.0$ and $10 \mu \mathrm{g} / \mathrm{mL}$ cortisol (Sigma) $(n=6-8)$. In a subsequent incubation, filaments were treated with oPrl $(5 \mu \mathrm{g} / \mathrm{mL})$, cortisol $(1 \mu \mathrm{g} / \mathrm{mL})$, or the combination of both hormones $(n=6-8)$. Finally, we incubated filaments in medium supplemented with $\operatorname{tPrl}_{177}$ or $\operatorname{tPrl}_{188}$ at 0 , $0.01,0.1,0.5$, and $1.0 \mu \mathrm{g} / \mathrm{mL}(n=8)$. oPrl concentrations were selected following Inokuchi and coworkers (2015); tPrl concentrations were selected on the basis that $\operatorname{tPrl}_{177}$ and $\operatorname{tPrl}_{188}$ levels range between 0 and 90 and 0 and $35 \mathrm{ng} / \mathrm{mL}$, respectively (Breves et al. 2011). Cortisol concentrations were selected based upon previous experiments employing gill block incubation (Kiilerich et al. 2007). tPrls were purified from media following pituitary tissue incubation (Breves et al. $2014 b$ ). All incubations were maintained for $8 \mathrm{~h}$ at $26^{\circ} \mathrm{C}$; incubations were terminated by collecting the filaments in TRI Reagent (MRC, Cincinnati, OH, USA) for RNA isolation.

\section{RNA isolation, CDNA synthesis, and quantitative real-time PCR}

Total RNA was isolated from gill filaments with TRI Reagent according to the manufacturer's protocol. RNA concentration and purity were assessed by spectrophotometric absorbance (Nanodrop 1000, Thermo Scientific). The first-strand cDNA was synthesized with a High Capacity cDNA Reverse Transcription Kit (Life Technologies). Relative levels of mRNA were determined by quantitative real-time PCR (qPCR) using the StepOnePlus Real-Time PCR System (Life Technologies). aqp3, ef1 $\alpha$ and gapdh primer sequences and cycling parameters are described by Watanabe and coworkers (2005), Breves and coworkers (2010b), and Tang and Lee (2010), respectively. The mRNA levels of normalization (ef1 $\alpha$ or gapdh) and target (aqp3) genes were determined by the relative quantification method as specified by StepOne Software v2.0 (Life Technologies) after verification that normalization genes did not vary across treatments. Standard curves were prepared from serial dilutions of untreated gill cDNA and included on each plate to calculate PCR efficiencies. Relative gene expression ratios between treated and control groups are reported as a fold change from controls. Reverse transcription negative control reactions confirmed the absence of contaminating genomic DNA.

\section{Whole-mount immunofluorescence staining}

A polyclonal antibody was used for the detection of tilapia Aqp3 that recognizes amino acids 290-303; the production of anti-tilapia Aqp3 has been described previously (Watanabe et al. 2009). Fixed samples were rehydrated in PB with $0.2 \%$ Triton-X 100 (PBST) and immersed in blocking buffer (PBST containing 10\% normal goat serum, $0.1 \%$ bovine serum albumin, $0.02 \%$ keyhole limpet hemocyanin, and $0.01 \%$ sodium azide). After blocking, each specimen was incubated at $4^{\circ} \mathrm{C}$ overnight with anti-Aqp3 (1:1000) diluted with blocking buffer. After several washes with PBST, samples were incubated overnight at $4^{\circ} \mathrm{C}$ with goat anti-rabbit IgG labeled with Alexa Fluor 488 (Invitrogen) diluted 1:500. After rinsing with PBST, the specimens were observed under a confocal laser scanning microscope (LSM 710, Zeiss). The afferent-vascular edges of gill filaments were examined for a minimum of four individuals per treatment. For localization of $\mathrm{Na}^{+} / \mathrm{Cl}^{-}$cotransporter (Ncc) in incubated filaments, a T4 monoclonal antibody (developed by Christian Lytle and Bliss Forbush III, and obtained from the Developmental Studies Hybridoma

Published by Bioscientifica Ltd. 
Bank, Iowa City, IA, USA) was used as described previously (Lytle et al. 1995, Inokuchi et al. 2008).

\section{Western blotting analysis}

Gill filaments collected from FW-acclimated tilapia were lysed in $0.5 \%$ SDS and $50 \mathrm{mM}$ sodium phosphate $(\mathrm{pH} 7.5)$ by sonication. After centrifugation at $10,000 \mathrm{~g}$ and $4^{\circ} \mathrm{C}$ for $10 \mathrm{~min}$, the supernatant was collected. About $20 \mu \mathrm{L}$ of this sample was used for BCA assay (Thermo Scientific) to determine protein concentration. Dithiothreitol was added to the sample (final concentration: $40 \mathrm{mM}$ ) and proteins were denatured at $100^{\circ} \mathrm{C}$ for $10 \mathrm{~min}$ in a water bath and then chilled on ice for $5 \mathrm{~min}$. The resulting sample was separated by SDS-PAGE at $200 \mathrm{~V}$ for $50 \mathrm{~min}$. After separation, the proteins were transferred to a PVDF membrane with CAPS transfer buffer (10 mM CAPS, pH 11). The PVDF membrane was immersed in blocking buffer
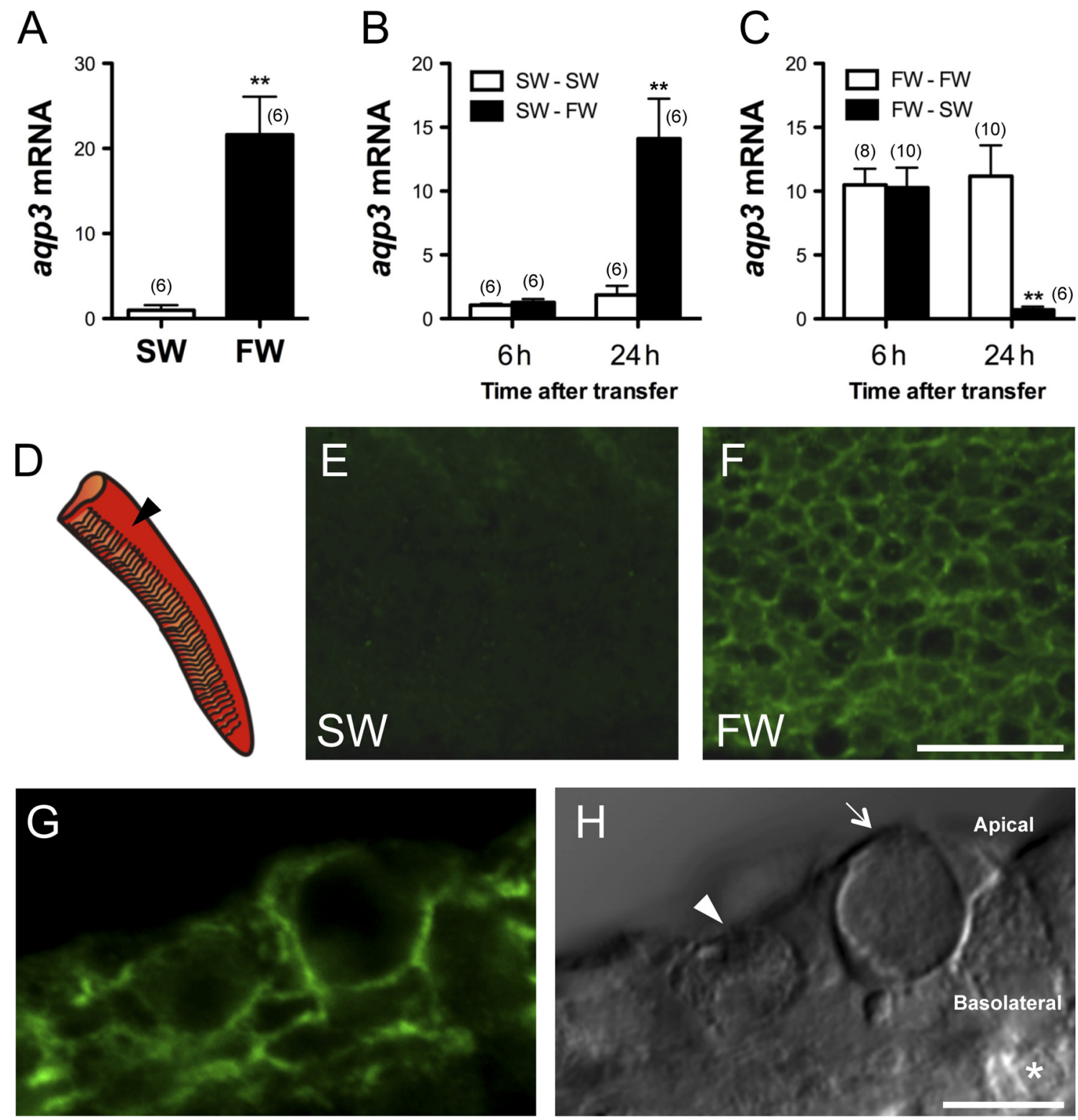

Figure 1

aqp3 expression in SW- vs FW-acclimated animals (A) and following the transfer from SW to FW (B), or FW to SW (C). Data are presented as mean \pm S.E.M. Sample size is indicated within parentheses. **Significant difference from time-matched controls at $P<0.01$ by Mann-Whitney $U$ test. Immunofluorescent staining for Aqp3 in the afferent-vascular edges of gill filaments (D, arrowhead) of tilapia acclimated to SW (E) or FW (F). Scale bar $=50 \mu \mathrm{m}$. Cross-sectional view of FW filament with Aqp3 staining (G) and by DIC (H). Arrowhead=ionocyte, arrow =mucous cell, asterisk = basement membrane. Scale bar $=10 \mu \mathrm{m}$. 
(5\% skimmed milk in $20 \mathrm{mM}$ Tris-buffered saline with 0.1\% Tween-20 (TBST)) for $30 \mathrm{~min}$ at room temperature, and then incubated overnight at $4^{\circ} \mathrm{C}$ with anti-tilapia Aqp3 diluted 1:4000 with blocking buffer. After several washes with TBST, the membrane was incubated with HRPconjugated anti-rabbit IgG (Cell Signaling Technology) diluted 1:5000 with blocking buffer for $3 \mathrm{~h}$ at room temperature. The immunopositive band was detected using a chemiluminescence method with EzWestLumi One (Atto, Tokyo, Japan).

\section{Statistical analyses}

For experiment 1, aqp3 expression in SW- versus FW-acclimated animals was analyzed by Mann-Whitney $U$ test. Transfer experiments were analyzed by two-way analysis of variance (ANOVA) with treatment and time as main effects. When a significant effect of treatment or an interaction between treatment and time was detected, a Mann-Whitney $U$ test was employed at each time point. For experiments 2-4, group comparisons were performed by one-way ANOVA, followed by Tukey's HSD. When necessary (Shapiro-Wilk test), data were log transformed to meet assumptions of normality. When assumptions of homogeneity were not met (Bartlett's test), group comparisons were conducted by a Kruskal-Wallis test, followed by Dunn's test. All analyses were conducted using GraphPad Prism 5.0. The significance for all tests was set at $P<0.05$.

\section{Results}

\section{Experiment 1: effect of salinity on aqp3 gene expression and immunoreactivity}

aqp3 levels were roughly 20-fold higher in long-term FW- versus SW-acclimated tilapia (Fig. 1A). Following the transfer of tilapia from SW to FW or vice versa, aqp3 levels were modulated in a fashion to reflect 'steadystate' expression patterns by $24 \mathrm{~h}$ (Fig. $1 \mathrm{~B}$ and C). In both transfer paradigms, there were significant treatment, time, and interaction effects. In the afferent-vascular edges of gill filaments (Fig. 1D), we observed a marked difference in the level of Aqp3 immunoreactivity in SW- versus FW-acclimated tilapia (Fig. 1E and F); Aqp3 immunoreactivity was localized to cell membranes of branchial epithelium in filaments collected from FW-acclimated animals (Fig. 1F). Cross-sectional views revealed Aqp3 immunoreactivity in various epithelial cells, including ionocytes, mucous (goblet) cells and pavement

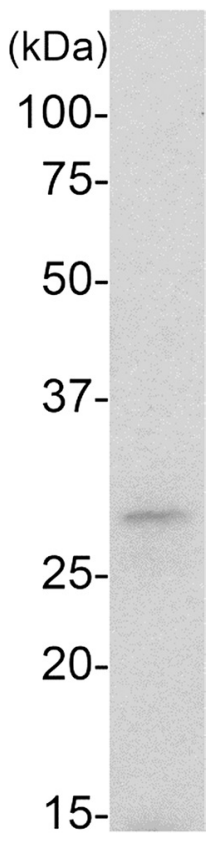

Figure 2

Western blotting analyses with an antibody raised against Aqp3 amino acids 290-303. Gill filaments were collected from FW-acclimated tilapia and protein samples were separated by SDS-PAGE. Positions of molecular mass markers $(\mathrm{kDa})$ are shown on the left. A single protein band with a molecular mass of $\sim 30 \mathrm{kDa}$ was detected. This $\sim 30 \mathrm{kDa}$ band corresponds to the predicted molecular mass of Aqp3 ( $33 \mathrm{kDa}$ ).

cells (Fig. 1G and H). Apical crypts characterize ionocytes, while mucous cells are larger and ovoid in shape (Wilson \& Laurent 2002, Kaneko et al. 2008). Pavement cells are the most abundant cells in brachial epithelium, a pattern consistent with the extensive Aqp3 immunoreactivity observed in filaments collected from FW-acclimated fish (Fig. 1F) (Wilson \& Laurent 2002). As specified previously, the first and second gill arches were sampled for gene and protein expression, respectively. Although we did not directly assess whether Aqp3 expression varied across arches, the strong agreement between Aqp3 gene and protein expression within a given salinity suggests that there were no overt differences in how Aqp3 was regulated across the sampled arches.

By Western blotting analysis, the Aqp3 antibody employed in this study recognized a single protein with a molecular mass of $\sim 30 \mathrm{kDa}$ (Fig. 2). As calculated from the translated amino acid composition of the aqp3 open reading frame (ExPASy), the molecular mass of Aqp3 is $33 \mathrm{kDa}$.

\section{Experiment 2: effect of Hx on Aqp3 expression}

To identify whether the pituitary mediates salinitydependent Aqp3 expression, we transferred Hx fish from

Published by Bioscientifica Ltd 
BW $(12 \%)$ to either SW or FW. In tilapia transferred to FW, Hx fish showed markedly reduced aqp3 expression compared with intact and sham-operated controls (Fig. 3A). Expression of aqp3 was considerably lower in all SW-treatment groups compared with intact and shamoperated fish in FW; there was no effect of $\mathrm{Hx}$ on aqp3 expression in SW. In parallel with diminished aqp3 levels in $\mathrm{Hx}$ animals in FW, we observed a clear reduction in Aqp3 immunoreactivity in branchial epithelium from $\mathrm{Hx}$ fish (Fig. 3D) compared with intact and sham-operated controls (Fig. 3B and C).

\section{Experiment 3: effect of hormones on Aqp3 expression in hypophysectomized tilapia}

Inasmuch as an intact pituitary was required for salinitydependent Aqp3 expression, we tested whether hormones (Prl, Gh and cortisol) either secreted by or under the control of the pituitary regulate Aqp3. In SW, there were no effects of any hormone, administered either alone or in combination, on aqp3 mRNA levels (Fig. 4A). In $\mathrm{Hx}$ animals in FW, oPrl stimulated aqp3 levels by 8.6-fold from vehicle-injected controls; oGh did not affect aqp3 levels. Although there was no effect of cortisol alone on aqp3 levels, cortisol was sufficient to block the effect of oPrl on aqp3 (Fig. 4B). Accordingly, Aqp3 immunoreactivity in the branchial epithelium of oPrl-injected animals was more intense than in vehicle-injected controls (Fig. 4C and $\mathrm{D})$. In contrast with aqp3 mRNA patterns, there was only a modest reduction in Aqp3 immunoreactivity in animals injected with oPrl and cortisol compared with vehicle-injected controls (Fig. 4C and E).

\section{Experiment 4: effects of oPrl, $\mathrm{tPrl}_{177}, \mathrm{tPrl}_{188}$, and cortisol on aqp3 expression in incubated gill filaments}

To assess whether Prl and cortisol regulate aqp3 expression in a gill-autonomous fashion, we incubated gill filaments in the presence or absence of Prl and/or cortisol for $8 \mathrm{~h}$. oPrl at 5 and $10 \mu \mathrm{g} / \mathrm{mL}$ stimulated the expression of aqp3 by $\sim 40$-fold from controls (Fig. 5A); cortisol did not impact aqp3 expression at any of the tested concentrations (Fig. 5B). In a subsequent incubation, we administered oPrl $(5 \mu \mathrm{g} / \mathrm{mL})$ alone or in combination with cortisol $(1 \mu \mathrm{g} / \mathrm{mL})$. Although the magnitude of response to oPrl was less robust in this subsequent experiment ( 4-fold vs 40-fold), cotreatment with cortisol blocked the ability of oPrl to stimulate aqp3 expression (Fig. 5C); this result was consistent with in vivo patterns (Fig. 4B). Mozambique tilapia secrete two Prl peptides from the pituitary, denoted $\mathrm{tPrl}_{177}$ and $\mathrm{tPrl}_{188}$ (Specker et al. 1985). We found that purified $\operatorname{tPrl}_{177}$ and $\mathrm{tPrl}_{188}$, compared with oPrl, stimulated aqp3 at a lower concentration (0.5 and 1 vs $5 \mu \mathrm{g} / \mathrm{mL}$ ) (Fig. 6).

In a separate experiment, we confirmed that our incubation techniques accurately model in vivo responses to oPrl by demonstrating an induction of Ncc immunoreactivity following $24 \mathrm{~h}$ of oPrl treatment
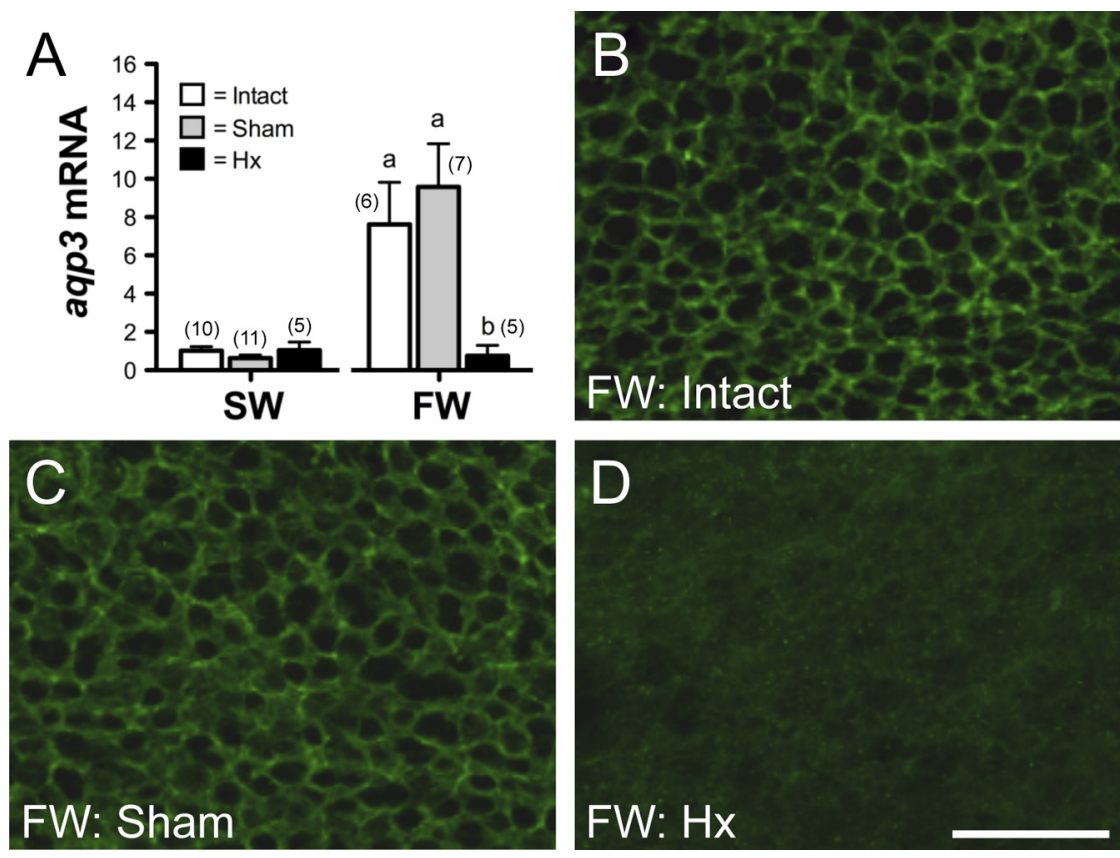

\section{Figure 3}

Effects of Hx on aqp3 expression following transfer to SW or FW (A). Data are presented as mean \pm S.E.M. Sample size is indicated within parentheses. Five days after $\mathrm{Hx}$, intact (open bars), sham-operated (shaded bars), and $\mathrm{Hx}$ (solid bars) tilapia were transferred from BW (12\%0) to FW or SW and sampled after 3 days. Within a given environmental salinity, means not sharing the same letter are significantly different (one-way ANOVA, Tukey's HSD, $P<0.05)$. Immunofluorescent staining for Aqp3 in gill filaments of intact (B), sham-operated (C), and Hx tilapia (D) transferred to FW for 3 days. Scale bar $=50 \mu \mathrm{m}$. 

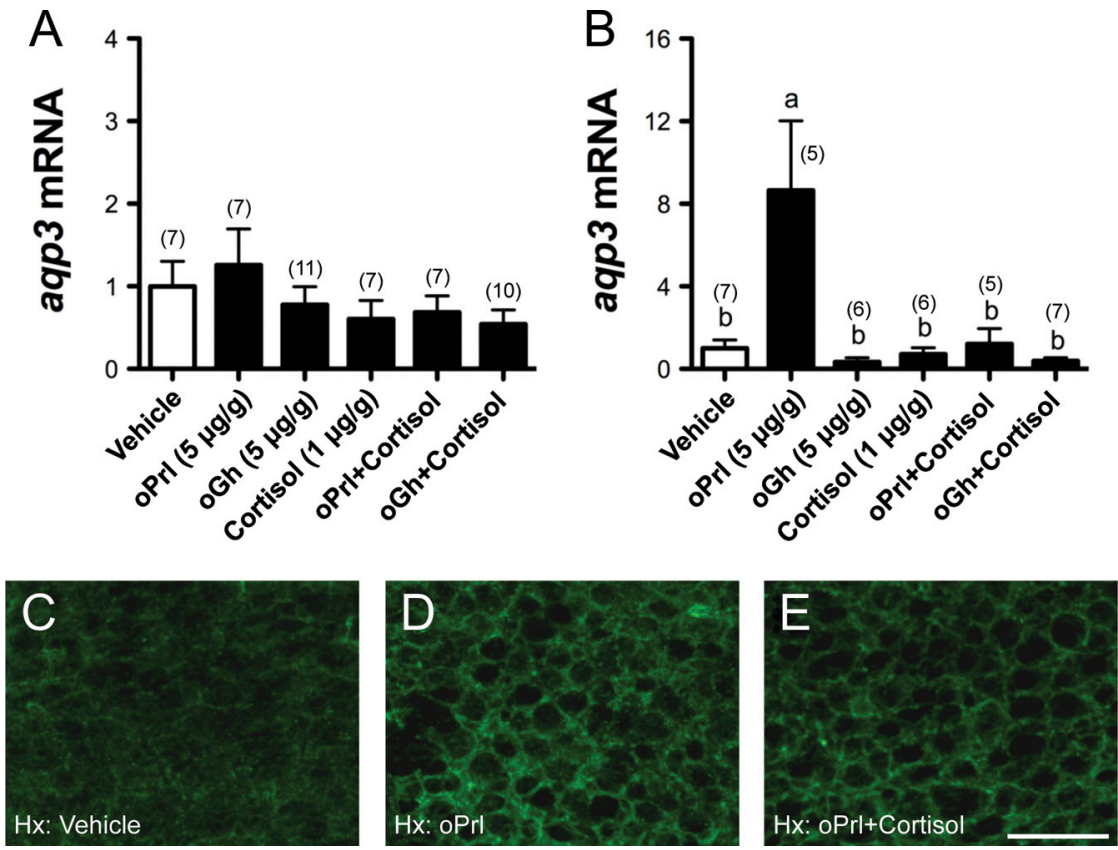

\section{Figure 4}

Effects of oPrl, oGh, and cortisol on branchial aqp3 expression in SW (A) and FW (B). Data are presented as mean \pm S.E.M. Sample size is indicated within parentheses. Fish received two intraperitoneal injections of oPrl $(5 \mu \mathrm{g} / \mathrm{g}$ body weight) or oGh $(5 \mu \mathrm{g} / \mathrm{g})$ alone or in combination with cortisol $(1 \mu \mathrm{g} / \mathrm{g})$. The first injection occurred immediately prior to transfer from BW (12\%) to SW or FW; the second occurred at $24 \mathrm{~h}$. Fish were sampled 3 days after initial transfer to SW or FW. $\mathrm{Hx}$ fish receiving saline injections (open bars) served as controls. Means not sharing the same letter are significantly different (one-way ANOVA, Tukey's HSD, $P<0.05$ ). Immunofluorescent staining for Aqp3 in gill filaments of tilapia transferred to FW injected with saline vehicle (C), oPrl (D) or oPrl +cortisol (E). Scale bar $=50 \mu \mathrm{m}$.
(Fig. 7); Ncc is an established target of Prl (Breves et al. 2010c, 2013, Inokuchi et al. 2015).

\section{Discussion}

We hypothesized that Prl, Gh, and/or cortisol participate in the regulation of salinity-dependent Aqp3 expression in euryhaline tilapia. Through a combination of experimental approaches, including salinity transfer, $\mathrm{Hx}$, hormone replacement and gill filament incubation, we provide evidence that Prl is both necessary and sufficient to promote Aqp3 expression within branchial epithelium. Moreover, we found that cortisol antagonizes the stimulatory effect of Prl on Aqp3 expression. We first discuss these regulatory patterns within the context of how plasma levels of Prl and cortisol vary during salinity acclimation of tilapia. We then consider the adaptive significance of these regulatory connections between Prl, cortisol and Aqp3.

We and others have shown that branchial aqp3 expression in teleosts is rapidly modulated in response to changes in salinity, with elevated expression in FW versus SW (Cutler \& Cramb 2002, Lignot et al. 2002, Tse et al. 2006, Tipsmark et al. 2010, Whitehead et al. 2010, Jung et al. 2012, Lam et al. 2014, Madsen et al. 2014, Moorman et al. 2015). Prl has long been recognized as "the FW-adapting hormone" in fishes based upon its capacity to support branchial processes essential to life in FW (Hirano 1986, McCormick 2001). Accordingly, euryhaline fishes exhibit dramatic changes in circulating Prl in parallel with salinity acclimation, with an inverse relationship between plasma Prl levels and ambient salinity. In Mozambique tilapia, plasma Prl rose by 4-6h after transfer from SW to FW (Yada et al. 1994, Seale et al. 2002, Kajimura et al. 2004, Breves et al. 2011). The latency of this Prl response to FW is consistent with the activation of aqp3 sometimes between 6 and $24 \mathrm{~h}$ following transfer (Fig. 1B). Our Hx and hormone replacement data, however, provide the strongest evidence that circulating Prl directs Aqp3 expression in FW (Figs 3 and 4). Both here and previously (Breves et al. 2010a), we observed a sharp attenuation of aqp3 expression following transfer from FW to SW. Recall that cortisol injected into oPrl-treated animals held in FW also attenuated aqp3 expression (Fig. 4B). As plasma cortisol responds more rapidly than Prl to SW transfer (Kajimura et al. 2004), cortisol released during the acute phase of SW acclimation is likely overriding the effect of Prl levels that have yet to fall. Cutler and coworkers (2002) reported that gill aqp3 was diminished in FW-acclimated eel infused with cortisol. Thus, inhibition of aqp3 by cortisol may constitute an important, and conserved, facet of SW acclimation by preventing excessive water loss across branchial epithelium, which would further threaten hydromineral balance. Interestingly, there was no effect of oPrl on aqp3a in incubated zebrafish (Danio rerio) gill filaments (J P Breves, unpublished observations). As zebrafish are stenohaline, a Prl-aqp3 regulatory connection may be restricted to euryhaline species routinely exposed to varying salinities. Clearly, a wider

Published by Bioscientifica Ltd 

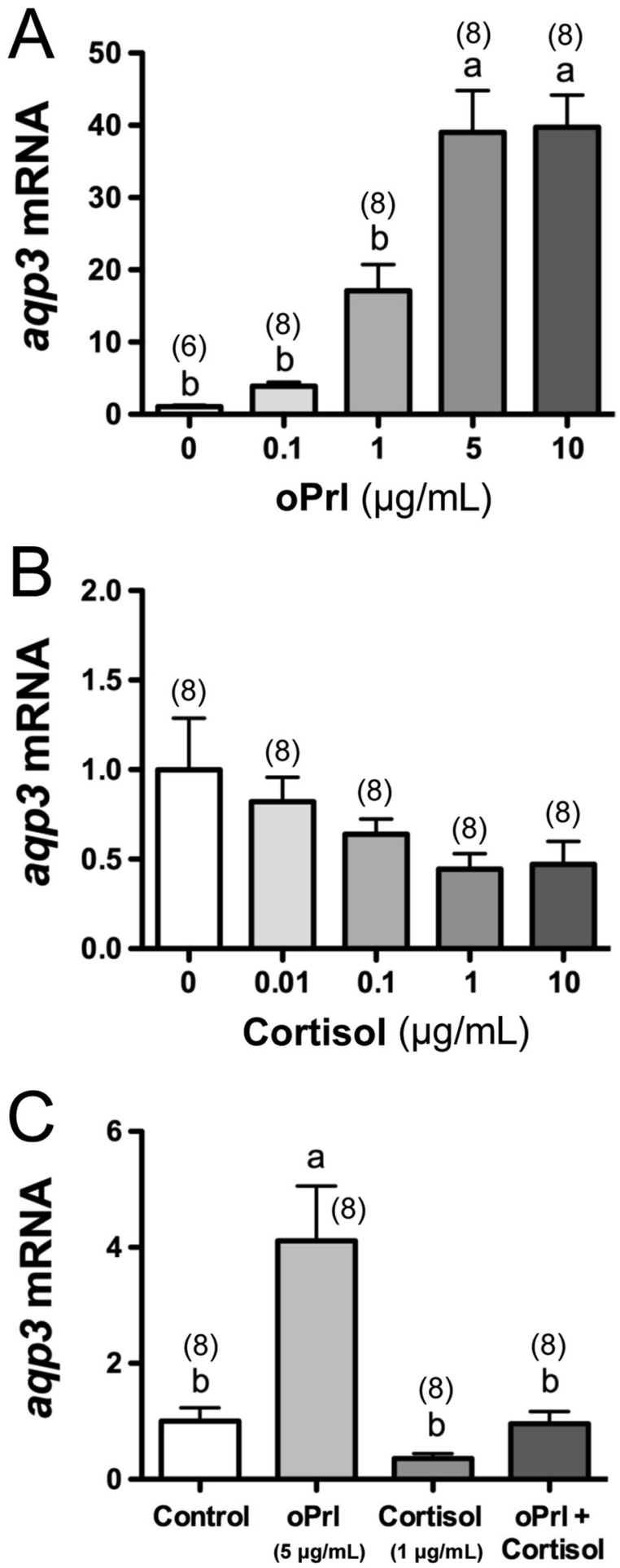

Figure 5

Effects of oPrl (A) and cortisol (B) concentration on aqp3 expression in gill filaments incubated for $8 \mathrm{~h}$. Effect of cortisol on basal and oPrl-stimulated aqp3 expression (C). Data are presented as mean \pm S.E.M. Sample size is indicated within parentheses. aqp3 expression is presented as a fold change from the zero concentration groups. Means not sharing the same letter are significantly different (one-way ANOVA or Kruskal-Wallis, Tukey's HSD or Dunn's test, $P<0.05$ )
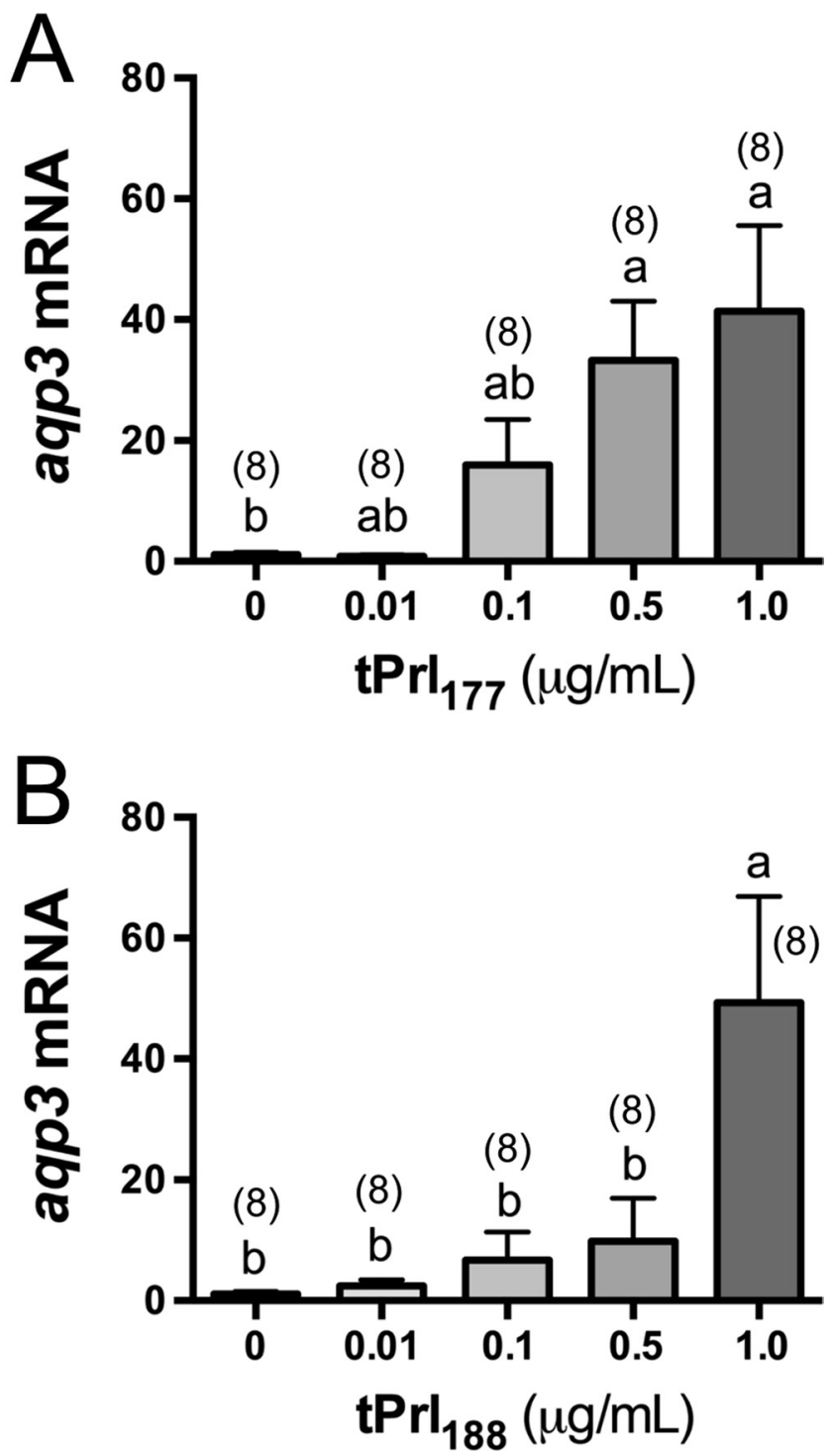

Figure 6

Effects of native $\operatorname{tPrl}_{177}(\mathrm{~A})$ and $\mathrm{tPrl}_{188}$ (B) concentration on aqp3 expression in gill filaments incubated for $8 \mathrm{~h}$. Data are presented as mean \pm S.E.M. Sample size is indicated within parentheses. aqp3 expression is presented as a fold change from the zero concentration groups. Means not sharing the same letter are significantly different (one-way ANOVA or Kruskal-Wallis, Tukey's HSD or Dunn's test, $P<0.05$ ).

suite of teleosts must be surveyed to resolve the degree to which Prl and Aqp3 are linked, and how it relates to salinity tolerance.

The rapid attenuation of aqp3 by SW, cortisol, and tidally driven changes in salinity suggests that Aqp3 function in the gill is maladaptive to life in SW (Cutler et al. 2007, Breves et al. 2010a, Moorman et al. 2015). Accordingly, we observed that ambient salinity had an 'overriding' effect on whether Prl stimulated aqp3 (Fig. 4A and B). In other words, salinity-dependent systemic and/or

Published by Bioscientifica Ltd 

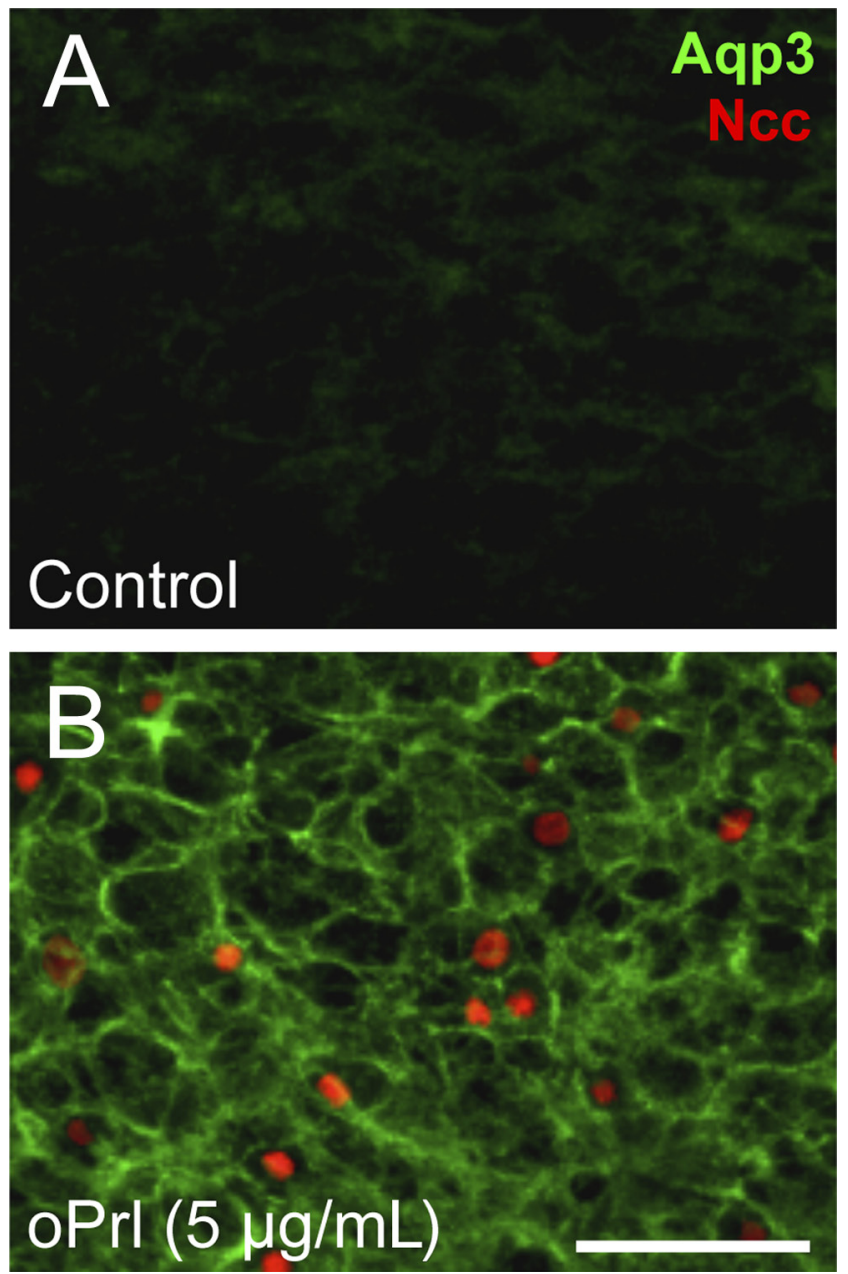

Figure 7

Immunofluorescent staining for Aqp3 (green) and Ncc (red) in gill filaments incubated for $24 \mathrm{~h}$ with control (A) or oPrl-supplemented (B) medium. Scale bar $=50 \mu \mathrm{m}$.

local factors seemingly modulate branchial responsiveness to Prl. Osmotic/ionic conditions (external and/or internal) are plausible modulators of Prl responsiveness. Thus, our future work will combine tPrl treatments with varying osmotic conditions in vitro to dissect the nature of these interactions. Moreover, we tested in vitro effects of Prl on filaments collected from FW-acclimated animals. In Atlantic salmon, in vitro hormone responsiveness (cortisol) was impacted by the salinity in which donor animals were maintained (Kiilerich et al. 2007). It will be interesting to learn whether filaments isolated from FW-acclimated tilapia are more responsive to Prl given their higher expression levels of Prl receptors compared with SW-acclimated tilapia (Breves et al. 2011).

The question of how Aqp3 underlies distinct branchial function(s) remains unanswered. Multiple investigators have approached this question by localizing
Aqp3 protein in gill tissue. In eel (Anguilla anguilla), killifish (Fundulus heteroclitus), and rainbow wrasse (Coris julis), Aqp3 immunoreactivity was observed in basolateral membrane of ionocytes (Lignot et al. 2002, Brunelli et al. 2010, Jung et al. 2012). Here, we observed extensive Aqp3 immunoreactivity in ionocytes, mucous cells, and pavement cells of the afferent-vascular edges of FW filaments (Fig. 1F, G and $\mathrm{H}$ ). We propose that Aqp3 confers osmoreceptivity in these branchial cell types. Aqp3 plays a well-characterized, and essential, role in mediating osmoreception in Prl cells of the tilapia pituitary (Watanabe et al. 2009). For example, the inhibition of Aqp3-mediated water movement by mercury treatment abolished the osmotically driven cell volume increases that follow reductions in extracellular osmolality (Watanabe et al. 2009). These cell volume changes are essential to coupling extracellular conditions with appropriate Prl release via the stretch-activated $\mathrm{Ca}^{2+}$ channel, transient receptor potential vanilloid 4 (Seale et al. 2003, Watanabe et al. 2012). Therefore, if the presumed role of branchial Aqp3 is to facilitate changes in cell volume, as in the pituitary, then Prl may play a key role in supporting osmosensitivity in the gill via Aqp3. For example, we have recently characterized the in vitro capacity of tilapia ionocytes to modulate ion transporter expression in response to changes in medium osmolality. These modulations of gene expression occurred in response to plasma osmotic conditions routinely experienced during the acute phases of FW $(\sim 280 \mathrm{mOsm} / \mathrm{kg})$ and SW $(\sim 450 \mathrm{mOsm} / \mathrm{kg}$ ) acclimation (Inokuchi et al. 2015). Hyperosmotic conditions stimulate the gene expression of $\mathrm{Na}^{+} / \mathrm{K}^{+} / 2 \mathrm{Cl}^{-}$cotransporter $1 \mathrm{a}(n k c c 1 a)$, a key cotransporter underlying ion extrusion by teleost ionocytes (Kaneko et al. 2008, Inokuchi et al. 2015), as well as volume regulation by pavement cells (Tse et al. 2007). Thus, enhanced aqp3/Aqp3 expression in the basolateral region of branchial cells in FW-acclimated tilapia (Fig. 1A and F) may render epithelial cells competent to rapidly activate $n k c c 1 a$ expression in response to increases in plasma osmolality along the basolateral membrane. Our current observations do not exclude the possibility that Prl and cortisol regulate glycerol permeability in the gill via Aqp3, operating as an aquaglyceroporin. Unlike in murine skin where glycerol permeability (via Aqp3) was shown to play an important role in maintaining skin elasticity (Ma et al. 2002), the consequence(s) of glycerol accumulation/transport in the branchial epithelium of tropical fishes, such as tilapia, is unresolved.

Our in vitro results demonstrate that Prl and cortisol have the capacity to directly regulate aqp3

Published by Bioscientifica Ltd 
expression independent from additional systemic factors. Gill filament incubation is a practical approach to characterize branchial responses to hormones that do not require additional input from the intact animal. Depending upon how filaments are incubated, gillautonomous functions are maintained for 1-4 days (Kiilerich et al. 2007, Breves et al. 2013, Watanabe et al. 2016). In tilapia, Ncc-expressing ionocytes (type II ionocytes) are key effectors of $\mathrm{Cl}^{-}$uptake (Hiroi et al. 2008, Horng et al. 2009), and we have shown that Prl stimulates $n c c$ expression and the recruitment of Ncc-expressing ionocytes in vivo (Breves et al. 2010c). Employing the presence of Ncc-expressing ionocytes as readout of Prl responsiveness (Breves et al. 2010c, Inokuchi et al. 2015), we confirmed the utility of the filament incubation system to model physiological responses to $\operatorname{Prl}$ (Fig. 7). In agreement with the direct effects that we observed, receptors for Prl and cortisol are highly expressed in tilapia gill (Dean et al. 2003, Fiol et al. 2009). We are now poised to leverage in vitro approaches to resolve how cortisol antagonizes Prl in the context of Aqp3 expression. We hypothesize that cortisol inhibits signal transduction pathways (JAK2/STAT, PI3K, MEK) demonstrated to underlie Prl-stimulated osmoregulatory pathways (Ferlazzo et al. 2012).

In summary, our current data establish Aqp3 as a new target of Prl in a vertebrate. Although a demonstrable function for Aqp3 in teleost gill remains elusive, this apparent link between Prl and Aqp3 may provide a means to modulate the osmosensitivity of multiple branchial cell types. We also revealed a novel capacity for cortisol to block Prl-stimulated aqp3 transcription. This instance of Prl-cortisol antagonism, at play in the gill, operates in concert with the modulation of Prl cell function by cortisol. In the pituitary, cortisol inhibits Prl release within minutes via nongenomic mechanisms (Borski et al. 1991). Recent advances in our understanding of how the teleost gill operates at the molecular level have provided the fodder for identifying novel, and conserved, hormone targets (Breves et al. 2014a, Guh et al. 2015). For example, the connection between Prl and Ncc first identified in the tilapia gill has been recently found to operate in mouse and rat kidney. This Prl-Ncc link may contribute to hypertension in pregnant women (Rojas-Vega et al. 2015). Moreover, Aqp3 was localized to secretory alveolar cells of the rat mammary gland, but functional regulation of Aqp3 in this context remains unresolved (Matsuzaki et al. 2005). Future work in euryhaline fishes will thus continue to provide insight into how highly plastic osmoregulatory systems are regulated while simultaneously revealing conserved modes of hormone action in vertebrates.

\section{Declaration of interest}

The authors declare that there is no conflict of interest that could be perceived as prejudicing the impartiality of the research reported.

\section{Funding}

This research was supported by Skidmore College (Start-Up Funds and Faculty Development Grant; J P B), Japan Society for the Promotion of Science (research fellowship number 2440164; M I), NSF (grant number IOS-1119693; E G G), the Edwin W Pauley Foundation (2012), the National Oceanic and Atmospheric Administration (grant number NA14OAR4170071) which is sponsored by the University of Hawai'i Sea Grant College Program, SOEST (Project R/SS-12; A P S), the University of Hawai'i NSF EPSCoR program (grant number EPS-0903833) in support of the Core Genetics Facility at the Hawai'i Institute of Marine Biology, and the University of Hawai'i Sea Grant publication number UNIHI-SEAGRANTJC-15-02.

\section{References}

Bole-Feysot C, Goffin V, Edery M, Binart N \& Kelly PA 1998 Prolactin (PRL) and its receptor: actions, signal transduction pathways and phenotypes observed in PRL receptor knockout mice. Endocrine Reviews 19 225-268. (doi:10.1210/edrv.19.3.0334)

Borski RJ, Helms LMH, Richman NH \& Grau EG 1991 Cortisol rapidly reduces prolactin release and cAMP and ${ }^{45} \mathrm{Ca}^{2+}$ accumulation in the cichlid fish pituitary in vitro. PNAS 88 2758-2762.

Boury-Jamot M, Sougrat R, Tailhardat M, Le Varlet B, Bonté F, Dumas M \& Verbavatz JM 2006 Expression and function of aquaporins in human skin: is aquaporin-3 just a glycerol transporter? Biochimica et Biophysica Acta 1758 1034-1042. (doi:10.1016/j. bbamem.2006.06.013)

Breves JP, Fox BK, Pierce AL, Hirano T \& Grau EG 2010a Gene expression of growth hormone family and glucocorticoid receptors, osmosensors, and ion transporters in the gill during seawater acclimation of Mozambique tilapia, Oreochromis mossambicus. Journal of Experimental Zoology Part A: Ecological Genetics and Physiology $\mathbf{3 1 3}$ 432-441. (doi:10.1002/jez.613)

Breves JP, Hirano T \& Grau EG $2010 b$ Ionoregulatory and endocrine responses to disturbed salt and water balance in Mozambique tilapia (Oreochromis mossambicus) exposed to confinement and handling stress. Comparative Biochemistry and Physiology Part A: Molecular \& Integrative Physiology 155 294-300. (doi:10.1016/j. cbpa.2009.10.033)

Breves JP, Watanabe S, Kaneko T, Hirano T \& Grau EG 2010c Prolactin restores branchial mitochondrion-rich cells expressing $\mathrm{Na}+/$ Cl- cotransporter in hypophysectomized Mozambique tilapia. American Journal of Physiology 299 R702-R710. (doi:10.1152/ ajpregu.00213.2010)

Breves JP, Seale AP, Helms RE, Tipsmark CK, Hirano T \& Grau EG 2011 Dynamic gene expression of GH/PRL-family hormone receptors in gill and kidney during freshwater-acclimation of Mozambique tilapia. Comparative Biochemistry and Physiology Part A: Molecular \& Integrative Physiology 158 194-200. (doi:10.1016/j.cbpa.2010.10.030)

Breves JP, Serizier SB, Goffin V, McCormick SD \& Karlstrom RO 2013 Prolactin regulates transcription of the ion uptake $\mathrm{Na}^{+} /$ $\mathrm{Cl}^{-}$cotransporter ( $\mathrm{ncc}$ ) gene in zebrafish gill. Molecular and Cellular Endocrinology 369 98-106. (doi:10.1016/j.mce.2013.01.021) 
Breves JP, McCormick SD \& Karlstrom RO 2014a Prolactin and teleost ionocytes: new insights into cellular and molecular targets of prolactin in vertebrate epithelia. General and Comparative Endocrinology 203 21-28. (doi:10.1016/j.ygcen.2013.12.014)

Breves JP, Seale AP, Moorman BP, Lerner DT, Moriyama S, Hopkins KD \& Grau EG $2014 b$ Pituitary control of branchial NCC, NKCC and $\mathrm{Na}+, \mathrm{K}+$-ATPase $\alpha$-subunit gene expression in Nile tilapia, Oreochromis niloticus. Journal of Comparative Physiology B 184 513-523. (doi:10.1007/s00360-014-0817-0)

Brunelli E, Mauceri A, Salvatore F, Giannetto A, Maisano M \& Tripepi S 2010 Localization of aquaporin 1 and 3 in the gills of the rainbow wrasse Coris julis. Acta Histochemica 112 251-258. (doi:10.1016/j. acthis.2008.11.030)

Cerdà J \& Finn RN 2010 Piscine aquaporins: an overview of recent advances. Journal of Experimental Zoology Part A: Ecological Genetics and Physiology 313 623-650. (doi:10.1002/jez.634)

Cutler CP \& Cramb G 2002 Branchial expression of an aquaporin 3 (AQP3) homologue is downregulated in the European eel Anguilla anguilla following seawater acclimation. Journal of Experimental Biology 205 2643-2651.

Cutler CP, Martinez AS \& Cramb G 2007 The role of aquaporin 3 in teleost fish. Comparative Biochemistry and Physiology Part A: Molecular \& Integrative Physiology 148 82-91. (doi:10.1016/j.cbpa.2006.09.022)

Dean DB, Whitlow ZW \& Borski RJ 2003 Glucocorticoid receptor upregulation during seawater adaptation in a euryhaline teleost, the tilapia (Oreochromis mossambicus). General and Comparative Endocrinology 132 112-118.

Eckert SM, Yada T, Shepherd BS, Stetson MH, Hirano T \& Grau EG 2001 Hormonal control of osmoregulation in the channel catfish Ictalurus punctatus. General and Comparative Endocrinology 122 270-286. (doi:10.1006/gcen.2001.7633)

Ferlazzo A, Carvalho ES, Gregorio SF, Power DM, Canario AV, Trishitta F \& Fuentes J 2012 Prolactin regulates luminal bicarbonate secretion in the intestine of the sea bream (Sparus aurata L.). Journal of Experimental Biology 215 3836-3844. (doi:10.1242/jeb.074906)

Finn RN, Chauvigné F, Hildberg JB, Cutler CP \& Cerdà J 2014 The lineage-specific evolution of aquaporin gene clusters facilitated tetrapod terrestrial adaptation. PLOS ONE 9 e113686. (doi:10.1371/ journal.pone.0113686)

Fiol DF \& Kültz D 2007 Osmotic stress sensing and signaling in fishes. FEBS Journal 274 5790-5798. (doi:10.1111/j.1742-4658.2007.06099.x)

Fiol DF, Sanmarti E, Sacchi R \& Kültz D 2009 A novel tilapia prolactin receptor is functionally distinct from its paralog. Journal of Experimental Biology 212 2007-2015. (doi:10.1242/jeb.025601)

Guh YJ, Lin CH \& Hwang PP 2015 Osmoregulation in zebrafish: ion transport mechanisms and functional regulation. EXCLI Journal 14 627-659. (doi:10.17179/excli2015-246)

Herndon TM, McCormick SD \& Bern HA 1991 Effects of prolactin on chloride cells in opercular membrane of seawater-adapted tilapia. General and Comparative Endocrinology 83 283-289.

Hirano T 1986 The spectrum of prolactin action in teleosts. Progress in Clinical and Biological Research 205 53-74.

Hiroi J, Yasumasu S, McCormick SD, Hwang PP \& Kaneko T 2008 Evidence for an apical $\mathrm{Na}-\mathrm{Cl}$ cotransporter involved in ion uptake in a teleost fish. Journal of Experimental Biology $2112584-2599$. (doi:10.1242/jeb.018663)

Horng JL, Hwang PP, Shih TH, Wen ZH, Lin CS \& Yin LY 2009 Chloride transport in mitochondrion-rich cells of euryhaline tilapia (Oreochromis mossambicus) larvae. American Journal of Physiology 297 C845-C854. (doi:10.1152/ajpcell.00218.2009)

Inokuchi M, Hiroi J, Watanabe S, Lee KM \& Kaneko T 2008 Gene expression and morphological localization of NHE3, NCC and NKCC1a in branchial mitochondria-rich cells of Mozambique tilapia (Oreochromis mossambicus) acclimated to a wide range of salinities. Comparative Biochemistry and Physiology Part A: Molecular \& Integrative Physiology 151 151-158. (doi:10.1016/j.cbpa.2008.06.012)
Inokuchi M, Breves JP, Moriyama S, Watanabe S, Kaneko T, Lerner DT, Grau EG \& Seale AP 2015 Prolactin 177, prolactin 188 and extracellular osmolality independently regulate the gene expression of ion transport effectors in gill of Mozambique tilapia. American Journal of Physiology 309 R1251-R1263. (doi:10.1152/ ajpregu.00168.2015)

Jackson LF, McCormick SD, Madsen SS, Swanson P \& Sullivan CV 2005 Osmoregulatory effects of hypophysectomy and homologous prolactin replacement in hybrid striped bass. Comparative Biochemistry and Physiology Part B: Biochemistry and Molecular Biology 140 211-218. (doi:10.1016/j.cbpc.2004.10.004)

Jung D, Sato JD, Shaw JR \& Stanton BA 2012 Expression of aquaporin 3 in gills of the Atlantic killifish (Fundulus heteroclitus): effects of seawater acclimation. Comparative Biochemistry and Physiology Part A: Molecular \& Integrative Physiology 161 320-326. (doi:10.1016/j. cbpa.2011.11.014)

Kajimura S, Hirano T, Moriyama S, Vakkuri O, Leppaluoto J \& Grau EG 2004 Changes in plasma concentrations of immunoreactive ouabain in the tilapia in response to changing salinity: is ouabain a hormone in fish? General and Comparative Endocrinology 135 90-99.

Kaneko T, Watanabe S \& Lee KM 2008 Functional morphology of mitochondrion-rich cells in euryhaline and stenohaline teleosts. Aqua-BioScience Monographs 1 1-62. (doi:10.5047/ absm.2008.00101.0001)

Kiilerich P, Kristiansen K \& Madsen SS 2007 Cortisol regulation of ion transporter mRNA in Atlantic salmon gill and the effect salinity on the signaling pathway. Journal of Endocrinology 194 417-427. (doi:10.1677/JOE-07-0185)

Konno N, Hyodo S, Yamaguchi Y, Matsuda K \& Uchiyama M 2010 Vasotocin/V2-type receptor/aquaporin axis exists in Africa lungfish kidney but is functional only in terrestrial condition. Endocrinology 151 1089-1096. (doi:10.1210/en.2009-1070)

Lam SH, Lui EY, Li Z, Cai S, Sung WK, Mathavan S, Lam TJ \& Ip YK 2014 Differential transcriptomic analyses revealed genes and signaling pathways involved in iono-osmoregulation and cellular remodeling in the gills of euryhaline Mozambique tilapia, Oreochromis mossambicus. BMC Genomics 15 921. (doi:10.1186/14712164-15-921)

Lignot JH, Cutler CP, Hazon N \& Cramb G 2002 Immunolocalisation of aquaporin 3 in the gill and the gastrointestinal tract of the European eel Anguilla anguilla (L.). Journal of Experimental Biology 20 2653-2663.

Lytle C, Xu JC, Biemesderfer D \& Forbush B 3rd 1995 Distribution and diversity of Na-K-Cl cotransport proteins: a study with monoclonal antibodies. American Journal of Physiology 269 C1496-C1505.

Ma T, Hara M, Sougrat R, Verbavatz JM \& Verkman AS 2002 Impaired stratum corneum hydration in mice lacking epidermal water channel aquaporin-3. Journal of Biological Chemistry 277 17147-17153. (doi:10.1074/jbc.M200925200)

Madsen SS, Bujak J \& Tipsmark CK 2014 Aquaporin expression in the Japanese medaka (Oryzias latipes) in freshwater and seawater: challenging the paradigm of intestinal water transport? Journal of Experimental Biology 217 3108-3121. (doi:10.1242/jeb.105098)

Madsen SS, Engelund MB \& Cutler CP 2015 Water transport and functional dynamics of aquaporins in osmoregulatory organs of fishes. Biological Bulletin 229 70-92.

Marshall WS \& Grosell M 2006 Ion transport, osmoregulation and acidbase balance. In The Physiology of Fishes, pp 177-230. Eds DH Evans \& JB Claiborne. Boca Raton, FL, USA: CRC Press.

Matsuzaki T, Machida N, Tajika Y, Ablimit A, Suzuki T, Aoki T, Hagiwara H \& Takata K 2005 Expression and immunolocalization of water-channel aquaporins in the rat and mouse mammary gland. Histochemistry and Cell Biology 123 501-512. (doi:10.1007/s00418005-0753-x)

McCormick SD 2001 Endocrine control of osmoregulation in teleost fish. American Zoologist 41 781-794. (doi:10.1093/icb/41.4.781) 
Moorman BP, Lerner DT, Grau EG \& Seale AP 2015 The effects of acute salinity challenges on osmoregulation in Mozambique tilapia reared in a tidally changing salinity. Journal of Experimental Biology 218 731-739. (doi:10.1242/jeb.112664)

Nishioka RS 1994 Hypophysectomy of fish. In Biochemistry and Molecular Biology of Fishes: Analytical Techniques, pp 49-58. Eds PW Hochachka \& TP Mommsen. New York, NY, USA: Elsevier.

Papadopoulus MC \& Verkman AS 2013 Aquaporin water channels in the nervous system. Nature Reviews Neuroscience 14 265-277. (doi:10.1038/nrn3468)

Rojas-Vega L, Reyes-Castro LA, Ramirez V, Bautista-Perez R, Rafael C, Castaneda-Bueno M, Meade P, de Los Heros P, Arroyo-Garza I, Bernard V, et al. 2015 Ovarian hormones and prolactin increase renal $\mathrm{NaCl}$ cotransporter phosphorylation. American Journal of Physiology 308 F799-F808. (doi:10.1152/ajprenal.00447.2014)

Schultz ET \& McCormick SD 2013 Euryhalinity in an evolutionary context. In Euryhaline Fishes, pp 477-529. Eds SD McCormick, AP Farrell \& CJ Brauner. New York, NY, USA: Elsevier.

Seale AP, Riley LG, Leedom TA, Kajimura S, Dores RM, Hirano T \& Grau EG 2002 Effects of environmental osmolality on release of prolactin, growth hormone and ACTH from the tilapia pituitary. General and Comparative Endocrinology 128 91-101.

Seale AP, Richman NH 3rd, Hirano T, Cooke I \& Grau EG 2003 Evidence that signal transduction for osmoreception is mediated by stretch-activated ion channels in tilapia. American Journal of Physiology 284 C1290-C1296. (doi:10.1152/ajpcell.00532.2002)

Specker JL, King DS, Nishioka RS, Shirahata K, Yamaguchi K \& Bern HA 1985 Isolation and partial characterization of a pair of prolactins released in vitro by the pituitary of a cichlid fish, Oreochromis mossambicus. PNAS 82 7490-7494. (doi:10.1073/pnas.82.22.7490)

Tang CH \& Lee TH 2010 Ion-deficient environment induces the expression of basolateral chloride channel, ClC-3-like protein, in gill mitochondrion-rich cells for chloride uptake of the tilapia Oreochromis mossambicus. Physiological and Biochemical Zoology 84 54-67. (doi:10.1086/657161)

Tipsmark CK, Sørensen KJ \& Madsen SS 2010 Aquaporin expression dynamics in osmoregulatory tissues of Atlantic salmon during smoltification and seawater acclimation. Journal of Experimental Biology 213 368-379. (doi:10.1242/jeb.034785)
Tse WK, Au DW \& Wong CK 2006 Characterization of ion channel and transporter mRNA expressions in isolated gill chloride and pavement cells of seawater acclimating eels. Biochemical and Biophysical Research Communications 346 1181-1190. (doi:10.1016/j.bbrc.2006.06.028)

Tse WK, Au DW \& Wong CK 2007 Effect of osmotic shrinkage and hormones on the expression of $\mathrm{Na}^{+} / \mathrm{H}^{+}$exchanger- $1, \mathrm{Na}^{+} / \mathrm{K}^{+} / 2 \mathrm{Cl}$ cotransporter and $\mathrm{Na}^{+} / \mathrm{K}^{+}$-ATPase in gill pavement cells of freshwater adapted Japanese eel, Anguilla japonica. Journal of Experimental Biology 210 2113-2120. (doi:10.1242/jeb.004101)

Verkman AS 2012 Aquaporins in clinical medicine. Annual Review of Medicine 63 303-316.

Watanabe S, Kaneko T \& Aida K 2005 Aquaporin-3 expressed in the basolateral membrane of gill chloride cells in Mozambique tilapia Oreochromis mossambicus adapted to freshwater and seawater. Journal of Experimental Biology 208 2673-2682. (doi:10.1242/jeb.01684)

Watanabe S, Hirano T, Grau EG \& Kaneko T 2009 Osmosensitivity of prolactin cells is enhanced by the water channel aquaporin-3 in a euryhaline Mozambique tilapia (Oreochromis mossambicus). American Journal of Physiology 296 R446-R453. (doi:10.1152/ajpregu.90435.2008)

Watanabe S, Seale AP, Grau EG \& Kaneko T 2012 Stretch-activated cation channel TRPV4 mediates hyposmotically induced prolactin release from prolactin cells of mozambique tilapia Oreochromis mossambicus. American Journal of Physiology 302 R1004-R1011. (doi:10.1152/ ajpregu.00632.2011)

Watanabe S, Itoh K \& Kaneko T 2016 Prolactin and cortisol mediate the maintenance of hyperosmoregulatory ionocytes in gills of Mozambique tilapia: exploring with an improved gill incubation system. General and Comparative Endocrinology 232 151-159. (doi:10.1016/j.ygcen.2016.04.024)

Whitehead A, Galvez F, Zhang S, Williams LM \& Oleksiak MF 2010 Functional genomics of physiological plasticity and local adaptation in killifish. Journal of Heredity 102 499-511. (doi:10.1093/jhered/esq077)

Wilson JM \& Laurent P 2002 Fish gill morphology: inside out. Journal of Experimental Zoology 293 193-213. (doi:10.1002/jez.10124)

Yada T, Hirano T \& Grau EG 1994 Changes in plasma levels of the two prolactins and growth hormone during adaptation to different salinities in the euryhaline tilapia, Oreochromis mossambicus. General and Comparative Endocrinology 93 214-223. (doi:10.1006/ gcen.1994.1025)

Received in final form 3 June 2016

Accepted 29 June 2016

Accepted Preprint published online 8 July 2016
() 2016 Society for Endocrinology Printed in Great Britain 